Škoda, M., Lengyelfalusy, T., \& Gabrhelová, G. (2017). Creative accounting practicies in Slovakia after passing financial crisis. Copernican Journal of Finance \& Accounting, 6(2), 71-86. http:// dx.doi.org/10.12775/CJFA.2017.012

\author{
MirosLAV ŠKODA*
}

TOMÁš LENGYELFALUSY

Gabriela Gabrhelová

DTI University, Slovakia

\title{
Creative accounting practicies IN SLOVAKIA AFTER PASSING FINANCIAL CRISIS
}

Keywords: accounting ethics, creative accounting, earnings management, GAAP, IFRS, financial reporting.

J E L Classification: G12, M41, M 48.

Abstract: Fraud in economics and accounting is the practice which is adopted within the framework of accounting system or in other words taking undue advantage of loopholes of accounting system is creative accounting. In highly competitive market, it becomes very important and necessary for every business to find new and innovative ways of running the business. And one of the new ways is creative accounting. Creative accounting is an art of manipulating the books of accounts in a manner that desired results can be drawn. Aggressive accounting, cooking the books and massaging the numbers are few common terms used in context of creative accounting. Creative accounting in present uncertain environment is facilitating management to accomplish personal goals as big, well established firms followed.

Date of submission: July 24, 2017; date of acceptance: October 5, 2017.

* Contact information: skoda@dti.sk, DTI University, Sladkovicova 533/20, 01841 Dubnica nad Vahom Slovakia, phone: 00421908906399. 


\section{IIINTRODUCTION}

Traditional accounting was limited to recording, classifying and summarizing the monetary results and communicating the same to investors. But modern accounting demands higher level of transparency with accurate reporting of financial position of the firm. The change has been seen in modern accounting system after a change in financial market caused by financial crisis in 2008-2009. Companies are also taking active part in obtaining funds through market. As the contribution of public funds increased in the corporate sector, the demand of transparency also increased and thus the way of managing books has also changed. Companies are trying to find out methods whereby they can provide full transparency and simultaneously accomplish their personal goals. At first, some definition of creative accounting is provided after introduction of theme of paper. After that, different motivations for its uses and several creating accounting techniques are have sought to identify its existence, nature and incidences.

Subject of fraud accounting is normally portrayed maligned and negative act. As soon as these words "fraud or creative accounting" are mentioned, the image that emerges in one's mind is that of manipulation, dishonesty and deception. According to agency theory 'the firm is a legal fiction which serves as a focus for a complex process in which the conflicting objectives of individuals are brought into equilibrium within a framework of contractual relations.' Within the agency framework, it is both logical and inescapable that management behaviour will be self-serving. Agency can, therefore, provide a solid framework for the understanding of creative accounting behaviour. However, it may provide an incomplete theoretical basis for explaining or predicting management behaviour; the ethical dimension of human behaviour may provide an important element missing from legalistic and adversarial agency relationships.

The informational perspective is a key element underpinning the study of the creative accounting phenomenon. A conflict is created by the information asymmetry that exists in complex corporate structures between a privileged management and a more remote body of stakeholders. Managers may choose to exploit their privileged position for private gain, by managing financial reporting disclosures in their own favour. The informational perspective assumes that accounting disclosures have an information content that possesses value to stakeholders in providing useful signals. 
It may be difficult or impossible for individual stakeholders to discern the fact and the effect of accounting manipulation, because of an insufficient personal skill set, indifference or an unwillingness to engage in detailed analysis. From a market efficiency perspective such failures in understanding may not matter. Breton and Taffler (2001) point out in the conclusion to their study establishing that analysts' perception of creative accounting devices is somewhat deficient, only a small number of effective accounting experts may be required 'for the market as a whole appropriately to process window dressed numbers'. On the other hand, Healy and Wahlen (1999) cite studies that find that creative accounting prior to equity issues does affect share prices, suggesting that investors do not necessarily see through creative accounting.

\section{LITERATURE OVERVIEW}

Creative accounting is referred to also as income smoothing, earnings management, earnings smoothing, financial engineering and cosmetic accounting. The preferred term in the USA, and consequently in most of the literature on the subject is 'earnings management', but in Europe the preferred term is 'creative accounting' or 'fraud accounting' and so this is the term that will be used in this paper. It should be recognized that some accounting manipulation involves primarily balance sheet rather than earnings management.

Various research studies have examined the issue of management motivation towards creative accounting behaviour. Half a century ago, Hepworth (1953) identified several motivations including the existence of tax levies based on income, confidence by shareholders and workers in management that is able to report stable earnings and psychological expectations relating to increases or decreases in anticipated income. Tax is mentioned as a significant motivator also by Niskanen and Keloharju (2000) in a Finnish context and in Japan by Herrmann and Inoue (1996). In countries with highly conservative accounting systems the 'income smoothing' effect can be particularly pronounced because of the high level of provisions that accumulate. Another bias that sometimes arises is called 'big bath' accounting, where a company making a bad loss seeks to maximise the reported loss in that year so that future years will appear better.

Beidleman (1973) observes the positive effects of income smoothing on expectations, securities valuation and some element of risk reduction for analysts. Other motivations for creative accounting discussed by Healy and Wahlen (1999) include those provided when significant capital market transactions 
are anticipated, and when there is a gap between the actual performance of the firm and analysts' expectations.

A variant on income smoothing is to manipulate profit to tie in to forecasts. Fox (1997) reports on how accounting policies in some companies are designed, within the normal accounting rules, to match reported earnings to profit forecasts. When these companies sell products, large part of the profit is deferred to future years to cover potential upgrade and customer support costs. This perfectly respectable, and highly conservative, accounting policy means that future earnings are easy to predict.

Healy (1985) examines managers' earnings manipulations motives where executive compensation is linked to income measurement. Trueman and Titman (1988) discuss managers' motivations to reduce the perception of variability in underlying economic earnings of the firm. Kamin and Ronen (1978) observe a difference in motivation between managers in owner - controlled and management - controlled firms. Owners who wish to retain control of a sizeable stake and who are therefore not interested in immediate exit strategies are less likely to be motivated to manage earnings.

Fraud accounting may help maintain or boost the share price both by reducing the apparent levels of borrowing, so making the company appear subject to less risk, and by creating the appearance of a good profit trend. This helps the company to raise capital from new share issues, offer their own shares in takeover bids, and resist takeover by other companies. If the directors engage in 'insider dealing' in their company's shares they can use creative accounting to delay the release of information for the market, thereby enhancing their opportunity to benefit from inside knowledge.

It should be noted that, in an efficient market, analysts will not be fooled by cosmetic accounting charges. Indeed, the alert analyst will see income - boosting accounting changes as a possible indicator of weakness. Dharan and Lev (1993) report on a study showing poor share price performance in the years following income increasing accounting changes. Another set of reasons for creative accounting, which applies to all companies, arises because companies are subject to various forms of contractual rights, obligations and constraints based on the amounts reported in the accounts. 


\section{RESEARCH METHODOLOGY AND RESEARCH PROCESS}

This study identifies and explains the most common accounting practice situations that generate an artificial growth of the accounting result and that lie at the threshold between creative accounting and accounting fraud. Some of these situations have also been promoted by large multinational companies in Slovakia, which, for some of them, have led to bankruptcy. What were the consequences of using creative accounting by companies in Slovakia? Can these manipulations be identified? If yes, what are the main elements that lead to the elements that have undergone changes?

To answer these questions, a regulatory study was conducted through the study of specialized literature. Starting from the above mentioned data, we initiated a market research based on survey, for finding out the opinion of individuals directly involved.

Detecting Creative Accounting Practices in Slovakia and their Impact on the Quality of Information Presented in Financial Statements in the management of financial accounting activity in companies. 200 questionnaires were given to be filled by employees of companies from 13 fields of activity, the results being processed with the SPSS program. Of these, 194 were answered, more exactly 23 partially and 171 completely, eventually becoming the centre of our research.

In this way, we can highlight the similarities and differences between the perception of entrepreneurs and accountants concerning then on-standard practices and how they see the limits of accounting and the way they use the influences of the activity in the business.

Also, the study results can shape the way of regarding the possibilities of detection and mitigation of accounting misleading data tools in a company's activity.

The research method used is based on information from secondary sources, namely documentation. We have chosen this method since it provides certain advantages in the research process - it is efficient in obtaining information, it allows the confrontation of the information it provides thus enhancing the level of reliability, requires a smaller information collection effort, the information obtained is more objective and, in certain cases, unique, providing information that is not available in other situations.

The main secondary sources used were external sources such as official documents, magazines and specialized publications, statistic counts, the me- 
dia, the internet, the documents of various companies analysed and specialized literature.

The research instrument used in the study was the identification and the actual analysis of the data obtained after documenting and grouping them according to their importance and their relevance for the theme of the paper. The main results of this research are discussed in upcoming text.

\section{MOTIVES FOR FRAUD ACCOUNTING}

Burgstahler and Eames (1998) conclude that firms manage earnings to meet financial analysts' forecasts. The managers are motivated for fixing financial statements for either managing position or profits. Following are important concerns for managers:

- to meet internal targets: the managers want to cook the books for meeting internal targets set by higher management with respect to sales, profitability and share prices,

- to meet external expectations: company has to face many expectations from its stakeholders. The employees and customers want long term survival of the company for their interests. Suppliers want assurance about the payment and long term relationships with the company. Company also wants to meat analyst's forecasts and dividend pay-out pattern,

- to provide income smoothing: companies want to show steady income stream to impress the investors and to keep the share prices stable. Advocates of this approach favour it on account of measure against the 'short-termism' of evaluating an investment on the basis of the immediate yields. It also avoids raising expectations too high to be met by the management,

- to make window dressing for obtaining a bank loan: window dressing can be done before acquisition or before taking a bank loan. Sweeney (1994) reports the tendency of companies nearing violation of debt covenants is twice or thrice to make income increasing accounting policy changes than other companies,

- taxation: fraud creative accounting may also be a result of desire for some tax benefit especially when taxable income is measured through accounting numbers, 
- change in management: there is another important tendency of new managers to show losses due to poor management of old management by some provisions. Fox (1997) found this tendency in US bank managers.

\section{TECHNIQUES OF FRAUD ACCOUNTING}

The potential for fraud accounting is found in six principal areas: regulatory flexibility, a dearth of regulation, a scope for managerial judgment in respect of assumptions about the future, the timing of some transactions, use of artificial transactions and finally the reclassification and presentation of financial numbers. Taking each of the six areas in turn:

Regulatory flexibility. Accounting regulation often permits a choice of policy; for example, in respect of asset valuation (IFRS permit a choice between carrying non-current assets at either revaluated amounts or depreciated historical cost). Business entities may, quite validly, change their accounting policies. As Schipper (1989) points out, such changes may be relatively easy to identify in the year of change, but are much less readily discernible thereafter.

Dearth of regulation. Some areas are simply not fully regulated. For example, there are (as yet) very few mandatory requirements in respect of accounting for stock options.

Management has considerable scope for estimation in discretionary areas. Mc Nichols and Wilson (1988), for example, examine the discretionary and nondiscretionary elements of the bad debts provision.

Genuine transactions can also be timed so as to give the desired impression in the accounts. As an example, suppose a business has an investment at historic cost which can easily be sold for a higher sales price, being the current value. The managers of the business are free to choose in which year they sell the investment and so increase the profit in the accounts.

Artificial transactions can be entered into both to manipulate balance sheet amounts and to move profits between accounting periods. This is achieved by entering into two or more related transactions with an obliging third party, normally a bank. The sale price under such a 'sale and leaseback' can be pitched above or below the current value of the asset, because the difference can be compensated for by increased or reduced rentals.

Reclassification and presentation of financial numbers are relatively underexplored in the literature. 


\section{PRESENCE OF CREATIVE ACCOUNTING IN SLOVAKIA}

Many size companies are indulged in creative accounting practices and investors have to carefully examine the books of accounts, its profits and cash flows. Question is raised on many giant firms which were directly or indirectly related with other foreign companies. Slovakia is still developing economy where corporate sector is contributing a major part in national income, and it is spreading its wings all over world where they get lots of opportunities to go for creative accounting as all countries have different accounting system which creates ambiguity in investor's mind. And thus number of accounting scandals is increasing in Slovakia.

As Skoda and Hrazdilova Bockova (2014) discuss in their study, creative accounting is prevailing in almost all the companies in Slovakia, the reason might be the increasing level of competition and dearth of sustaining in the market. Loopholes or weaknesses in Slovak accounting standards are facilitating the corporate sector to indulge in creative accounting practices. They find that where the relevant accounting standards are permissive managers will exploit the potential use of creative accounting. Such behaviours are curtailed once the provisions of accounting standards are tightened. But the loopholes are so common and prevailing in accounting standards in such a manner that even if certain loopholes are eliminated, the practice of creative accounting is likely to exist. Nobel research report highlighted the common manipulations in accounting records in Slovakia:

- revenue manipulation: recording revenues ahead of time and booking fictitious sales,

- expense manipulation,

- cash manipulation,

- invisible restatement of prior period accounts.

Most of the companies in Slovakia are taking undue advantage of weaknesses of accounting principles. Like as mentioned by Iceberg research report companies tend to show revenue which is not earned. This is also considered as aggressive accounting technique whereby revenue is shown in the books of accounts before the project is completed in effect of which revenue increases. Cash manipulation is one of the common practices followed by most of the companies.

It may be noted that in 1999, a year when the economy was in a relatively buoyant condition, the reported earnings of 9 firms were less than adjusted earnings. However, in 2000 and 2001 when Slovak economy was affected by 
an economic downturn, the position has been reversed. A clear majority of the companies under scrutiny in both years showed reported earnings higher than adjusted earnings. The results of the study over a three year time period suggest that the direction of creative accounting could be related to general economic conditions. This possibility was flagged by Merchant (1990).

However, there are some unusual features of Slovak accounting environment that merit special attention. First, audit report qualifications are common, even in respect of major listed companies; find that between in the years 1996-2000 the number of qualified audit opinions in the financial statements of listed Slovak companies fell but the number was still high in 2000 when 92 companies had audit qualifications. Second, a feature which is likely to elicit some surprise outside Slovakia, an element of creative accounting may be carried out with the collusion of the regulatory authorities. Supervising agencies may permit individual companies to adopt an accounting policy which contravenes current accounting regulation. Such authorisations are provided as a result of effective lobbying by either a company or representative companies within an industrial sector. Successful lobbying of this type demonstrates the power of influence that the business sector may have over government or its agencies. The practice of charging expenses to reserves rather than to the income statement may also be permitted.

All of the creative accounting behaviours identified in this study was identified through careful analysis of the financial statements. Some of the manifestations were easier to identify than others, but all should be observable by a reasonably well - informed user of the financial statements. The question may be asked: if the creative accounting behaviour is so obvious, can it properly be classified as creative accounting at all? However, the extent to which users of the statements actually do observe such relatively clear examples of creative accounting is uncertain. It has been observed that analysts' reports in Slovakia usually fail to mention the existence of audit report qualifications, special authorisations or other manifestations of creative accounting practices. Even quite clear signalling can be misinterpreted or ignored even by relatively sophisticated users (Breton \& Taffler, 1995). Furthermore, Dechow and Skinner (2000) argue that even if financial statements provide sufficient information to permit users to adjust for creative accounting, there would still be cause for concern over the value of the information content because of 'the possibility that certain investors rely completely on earnings numbers reported on the face of the income statement because their ability to process more sophisticat- 
ed information is limited'. The results of these researches show that some elements of overt creative accounting practices are common.

\section{ETHICS AND FRAUD ACCOUNTING}

Companies desire to show the report with the profit grow steadily. This report is done by having stipulation for liabilities and opposing assets value during good years so that the reported profit can be improved in bad years. The purpose of this method is to evaluate the sources generate in following years and prevent unachievable expectations. However, the investors have the right to be informed on the violation of trading provisions and the effects of income smoothing in profit trend. Revsine (1991) considers the main function of accounting is to supervise the contracts between managers and groups who provide the finance so that the market mechanisms function efficiently and able to pinpoint the possibilities in creative accounting. The text about the ethics of bias in the accounting policy regarding on creative accounting is evaluate at both 'macro' level of accounting regulator and 'micro' level in the management of individual.

Ruland (1984) differentiated the deontological view and teleological view which deontological view is where the moral rules apply actual actions whereas teleological view is action should be evaluated on the moral worth of outcome. However, Revsine (1991) tends to perceive deontological view in public sector and teleological view in private sector. Ruland (1984) also talk about difference between 'positive' responsibility and 'negative' responsibility. 'Positive' responsibility is the responsibility to exhibit unbiased account while 'negative' responsibility is the managers' responsibility for the state of affairs which they fail to avoid. Ruland thinks that 'duty to refrain' that involves preventing the bias inherent in creative accounting is more critical because of the three issues which are relentlessness, certainty of outcome and responsibility.

Creative accounting seems morally doubtful for those professional accountants. According to Price Waterhouse senior partner's observation (Conner, 1986), fraudulent reporting normally occurs among those above management level in which effective internal control are designed. Financial statement are commonly used to generate the delusion that company is in better condition than it actually is by misapplication of the accounting principles to cover the economic realities. 
Fischer and Rosenzweig (1995) and Merchant and Rockness (1994) discovered that accountants are favourable in violating the accounting rules while students are favourable in manipulating the transactions. The reasons are accountants may obtain rule-based approach to ethics and think that the violating of accounting rules is under their job scope which ethical judgment demanded.

Merchant and Rockness (1994) also discovered that motivation of management impact the accountants' attitudes to creative accounting. This motivation was to advance the company. Accountants and managers who protest the creative accounting might face the risk of ruining their reputation. Schilit (1997) reports case where the accountant's employer, food wholesaler who capitalizes the slotting expense and amortize it for ten years. The accountant noticed that the employer was against the accounting treatment. Therefore, he notified the auditors to force the company expense but amortize the slotting. The company unable to pursue the auditors approves the capitalization of slotting costs. Later, the accountant was set off for the reason contrast with the employer judgment. To avoid having the same fate with that accountant, there are some suggestions such as verify the acceptability of the accounting method and do not interrupt something which is legal to avoid offense. In addition, the accountant should present legal method to attain favourable outcome to the management and mistreatment should report to the appropriate supervisor. The principal investor in the company tried, unsuccessfully, to put pressure on the auditor to support the capitalization of the slotting costs.

\section{SUGGESTIONS FOR FUTURE DEVELOPMENT}

It seems clear that in general creative accounting is seen as a deceitful and undesirable practice. In this section we analyse some measures which can help to reduce the scope for creative accounting practices, identifying, where applicable, recent developments in IFRS. IFRS became the basic accounting law for all European listed companies from 2005. Accounting regulators who wish to curb creative accounting have to tackle each of these approaches in a different way:

- auditor can play an important role in prevention and detection of creative accounting practices. If company's auditor is well establish entity and has good track record then its auditing process may be trusted. But that auditor should not be the only auditor of the company, there should be more than one auditor and that also should be rotated periodically. So 
that familiarity between company and auditor does not lead to decrease in objectivity,

- proper system should be introduce to educate investors about the financial terms and its probable impact on financial position through providing booklet of methods adopted by the proposed company for various items in different situations and expected changes in special circumstances,

- existence of artificial entities should be carefully checked by its actual presence and actual business transacted through it,

- companies which are allowed to enter into Slovak market via mergers and acquisitions or any other mode should be clearly examined; their financial statements should be checked through two or more independent auditors under the supervision of government for preventing fraudulent activities to come into Slovak market, close examination of those transactions which are changed in special circumstances and reason behind it. And transactions with related parties should also be examined thoroughly,

- laws and regulations laid down by government should be strictly followed by imposing heavy penalties in case of non-application of such rules,

- introduction of gifts and rewards for employees for their participation in engagement and motivate them to disclose any manipulations going on in the company records by anyone can also work in eliminating or reduction in creative accounting practices,

- Slovak law system has a major problem of slow trail and delay in investigation which reduced the materiality of the case and hence motivates others to follow the same practices. Through fast trial and quick investigation can reduce the number of accounting fraudulent practices.

Scope for choice of accounting methods can be reduced by reducing the number of permitted accounting methods or by specifying circumstances in which each method should be used. Requiring consistency of use of methods also helps here, since a company choosing a method which produces the desired picture in one year will then be forced to use the same method in future circumstances where the result may be less favourable.

Abuse of judgement can be curbed in two ways. One is to draft rules that minimise the use of judgement. At one time, for example, company accountants tended to use the 'extraordinary item' part of the profit and loss account for items they wished to avoid including in operating profit. Again, the present 
rules of the IFRS have definitely abolished the category of 'extraordinary item' few years ago. Auditors also have a part to play in identifying dishonest estimates. The other is to prescribe 'consistency' so that if a company chooses an accounting policy that suits it in one year it must continue to apply it in subsequent years when it may not suit so well.

Artificial transactions can be tackled by invoking the concept of 'substance over form', whereby the economic substance rather than the legal form of transactions determines their accounting substance. Thus linked transactions would be accounted for as one whole. The timing of genuine transactions is clearly a matter for the discretion of management. However, the scope to use this can be limited by requiring regular revaluations of items in the accounts so that gains or losses on value changes are identified in the accounts each year as they occur, rather than only appearing in total in the year that a disposal occurs. It is interesting to observe that the International Accounting Standards Board is still, after the times of financial crisis tending to move towards valuation at fair value rather than based upon historical cost in several recent accounting standards and discussion papers.

But apart from changes in accounting regulation, ethical standards and governance codes must be properly enforced in the corporate world. Regulation without thorough enforcement techniques is likely to be ineffective in preventing individuals from employing misleading reporting practices. The challenge of enforcing IFRS within a range of differing accounting cultural contexts is likely to be especially problematic.

\section{DisCUSSION AND CONCLUSIONS}

Slovak economy is not behind the other developed countries; in fact accounting fraud is prevalent more in developed countries. And in Slovakia such unethical practices are spreading its wings on fast pace just due to loopholes and weaknesses in accounting principles and standards. Through the study we found that companies are forced and under pressure of performing well and this becomes the major motivator of creative accounting, to be competitive and be in the race of competition, companies are trying to do anything whether it is unethical. And thus creative accounting becomes convenient way of sustainability. Secondly, we also found that this problem may exist due to lack of awareness and information level of investors. Government need to take quick action in awareness of the investors. Creative accounting practices are detected and 
prevented by various agencies in the country. Other countries should also take an adequate step in introduction of such law so that big accounting scandals can be eliminated from the economy.

Creative accounting results in reducing the tax liability of financial entities and, consequently, budgetary revenues. For this reason, creative accounting is closely related to tax evasion. Tax evasion occurs not only in Slovakia, but also in the countries of the European Union. In Slovakia, the total amount of tax evasion in 2011 was 2.773 billion EUR. According to statistical data of the European Union, the largest tax fraud in 2012 were in the value added tax in the amount of 117 billion EUR.

The Slovak Republic is fighting tax evasion by taking appropriate measures to reduce tax evasion. The fight against tax evasion is also performed by the Financial Administration and also by individual auditors. The Financial Administration annually improves the system of tax controls. Such improvements are related to modern approaches to control activities, and organisational management controls. Auditors have been obliged to notify the authorities of prosecuting tax evasion if it is of a criminal nature.

The fight against the tax evasion is an ongoing process, because tax evasion is a permanent malady that exists in the market society. Thus, to increase the budgetary revenues, great attention should be paid to the state of budgetary revenues.

It remains an open question, how to stabilize the business environment and how to establish a reasonable level of tax burden for countries so that tax heavens ceased to be attractive to business and businessmen were interested in promoting their activities in their own states.

\section{REFERENCES}

Beidleman, C.R. (1973). Income smoothing: the role of management. The Accounting Review, 48(10), 653-667, https://www.jstor.org/stable/245289?seq=1\#page_ scan_tab_contents (accessed: 25.05.2017).

Breton, G., \& Taffler, R.J. (1995). Creative accounting and investment analyst response. Accounting and Business Research, 25(9), 81-92, http://www.econjournals.com/ index.php/ijefi/article/viewFile/1047/pdf (accessed: 23.05.2017).

Burgstahler, D., \& Eames, M. (1998). Management of earnings and analysts' forecasts to achieve zero and small positive earnings surprises. University of Washington, working paper, http://onlinelibrary.wiley.com/doi/10.1111/j.1468-5957.2006.00630.x/ abstract (accessed: 25.05.2017). 
Conner, I.E. (1986). Enhancing public confidence in the accounting profession. Journal of Accountancy, 12(7), 76-83.

Dechow, P.M., \& Skinner, D.J. (2000). Earnings management: Reconciling the views of accounting academics, practitioners and regulators. Accounting Horizons, 14 (2), 235-251, https://papers.ssrn.com/sol3/papers.cfm?abstract_id=218959 (accessed: 27.05.2017). http://dx.doi.org/10.2139/ssrn.218959.

Dharan, B., \& Lev, B. (1993). The valuation consequence of accounting changes: a multi-year examination. Journal of Accounting Auditing and Finance, 8 (4), 475-494, http://baladharan.com/files/dharan-lev-accounting_changes-JAAF_2003.pdf (accessed: 25.05.2017). http://dx.doi.org/10.1177/0148558X9300800407.

Fischer, M., \& Rosenzweig. K. (1995). Attitudes of students and accounting practitioners concerning the ethical acceptability of earning management. Journal of Business Ethics, 14 (2), 433-444, https://link.springer.com/article/10.1007/BF00872085 (accessed: 25.05.2017). http://dx.doi.org/10.1007/bf00872085.

Fox, J. (1997). Learn to play the Earnings Game. Fortune, 1997-07-31, 5-8, http://archive.fortune.com/magazines/fortune/fortune_archive/1997/03/31/224039/index.htm (accessed: 21.04.2017).

Healy, P.M. (1985). The effect of bonus schemes on accounting decisions. Journal of Accounting and Economics, 7(3), 85-107. http://dx.doi.org/10.2308/acch.1999. 13.4.3651.

Healy, P.M., \& Wahlen, J.M. (1999). A review of the earnings management literature and its implications for standard setting. Accounting Horizons, 13(4), 67-77. https://doi. org/10.1016/0165-4101(85)90029-1 (accessed: 25.05.2017).

Hepworth, S.R. (1953). Smoothing periodic income. The Accounting Review, 15(1), 32-39, https://www.jstor.org/stable/241436?seq=1\#page_scan_tab_contents (accessed: 23.05.2017).

Hermann, D., \& Inoue, T. (1996). Income smoothing and incentives by operating condition: an empirical test using depreciation changes in Japan. Journal of International Accounting Auditing and Taxation, 5(2), 161-178. https://doi.org/10.1016/S10619518(96)90003-8 (accessed: 25.05.2017).

Iceberg research report (2015). Revealing financial manipulation and accounting frauds, https://iceberg-research.com/ (accessed: 20.10.2015).

Kamin, J.Y., \& Ronen, J. (1978). The smoothing of income numbers: some empirical evidence on systematic differences among management - controlled and owner - controlled firms. Accounting, Organizations and Society, 3(2), 141-157. https://doi. org/10.1016/0361-3682(78)90022-3 (accessed: 27.05.2017).

Mc Nichols, M., \& Wilson, G. P. (1988). Evidence of Earnings Management from the Provision for Bad Debts. Journal of Accounting Research, 26(1), 1-31, https://www.jstor.org/stable/2491176?seq=1\#page_scan_tab_contents (accessed: 23.05.2017).

Merchant, K.A. (1990). The effects of financial controls on data manipulation and management myopia. Accounting, Organizations and Society, 15(4), 297-313. https:// doi.org/10.1016/0361-3682(90)90021-L (accessed: 25.05.2017).

Merchant, K.A., \& Rockness, J. (1994). The ethics of managing earnings: an empirical investigation. Journal of Accounting and Public Policy, 13(1), 79-94. https://doi. org/10.1016/0278-4254(94)90013-2 (accessed: 23.05.2017). 
Niskanen, J., \& Keloharju, M. (2000). Earning cosmetics in a tax-driven accounting environment: evidence from Finnish public firms. The European Accounting Review, 9(3), 443-452. http://dx.doi.org/10.1080/09638180020017159 (accessed: 25.05.2017).

Revsine, L. (1991). The selective financial misrepresentation hypothesis. Accounting Horizons, 12(1), 16-27, https://blablawriting.com/the-selective-financial-misrepresentation-hypothesis-by-lawrence-revsine-essay (accessed: 21.04.2017).

Ruland, R.G. (1984). Duty, obligation and responsibility in accounting policy making. Journal of Accounting and Public Policy, 14(3), 223-237. https://doi. org/10.1016/0278-4254(84)90018-8 (accessed: 28.02.2017).

Schilit, H.M. (1997). Is it fraud or just slick accounting? CEO Magazine, 8-1997, 7-9.

Schipper, K. (1989). Commentary on earnings management. Accounting horizons. 12(2), 91-102.

Skoda, M. \& Hrazdilova Bockova, K. (2014). Study of culture of project oriented society. International Journal of Information Technology and Business management, 29(2), 167-180, http://www.jitbm.com/JITBM\%2029th\%20volume/2\%20project\%20 culture.pdf (accessed: 14.03.2017).

Sweeney, A.M. (1994). Debt-covenant violations and managers' accounting responses. Journal of Accounting and Economics, 17(4), 281-308. https://doi. org/10.1016/0165-4101(94)90030-2 (accessed: 25.05.2017).

Taffler, R., \& Breton, G. (2001). Accounting Information and Analyst Stock Recommendation Decisions: A Content Analysis Approach. Accounting and Business Research. 31(2), 91-101. http://dx.doi.org/10.1080/00014788.2001.9729604 (accessed: 27.05.2017).

Trueman, B., \& Titman, S. (1988). The explanation for accounting income smoothing. Journal of Accounting Research, 26(3), 127-139, https://www.jstor.org/ stable/2491184?seq=1\#page_scan_tab_contents (accessed: 01.06.2017). 